\title{
Transformations in the solid and liquid phase at aqueous carbonization of oil shale ash
}

\author{
M. Uibu, A. Trikkel \& R. Kuusik \\ Tallinn University of Technology, Laboratory of Inorganic Materials, \\ Ehitajate tee 5, Tallinn, Estonia
}

\begin{abstract}
The oil shale based energy sector of the Republic of Estonia is related to huge waste flows - about 5 million tons of waste ash is landfilled annually by circulating in the system tens of millions of cubic meters of transportation water saturated with different salts. Due to the distinctiveness of oil shale, the waste ash is characterized by heterogeneous and complicated mineral composition. Ash contains, depending on combustion technology (currently both pulverized firing and circulated fluidized bed combustion are used), $10-20 \%$ of free lime as the most active compound. Contacting free lime with water leads to elevated $\mathrm{pH}$ values $(\mathrm{pH}>13)$ and makes landfilling of this ash by hydraulic transportation highly problematic. It has been shown that the negative environmental impact of high alkalinity of these flows could be equilibrated by using $\mathrm{CO}_{2}$ from flue gases as a neutralizing agent. At the same time the emission of $\mathrm{CO}_{2}$ is diminished.

Laboratory batch tests showed that by treating ash - water suspension with $\mathrm{CO}_{2}$-containing flue gases, the most of the free $\mathrm{CaO}$ can be reduced to an acceptable level. Some aspects of processes deceleration during wet carbonization of ash have been elaborated. Part of the free $\mathrm{CaO}$ present is not accessible due to low porosity and the formation of reaction products on the surface of ash particles. Also, lowering the $\mathrm{pH}$ of carbonized ash suspension influences the composition of the liquid phase by increasing leaching of some of the ash components. The behaviour of $\mathrm{CaSO}_{4}$ as one of the dominant Ca-compounds in ash has been elaborated.
\end{abstract}

Keywords: $\mathrm{CO}_{2}$ mineralization, waste oil shale ash. 


\section{Introduction}

Extensive usage of low-grade solid fuels in the world energy production is accompanied by a variety of problems, including emission of greenhouse gases and safe deposition/utilization of solid wastes. Reducing $\mathrm{CO}_{2}$ emissions is an actual problem, being recognized and investigated by numerous research groups all over the world. One of the options is $\mathrm{CO}_{2}$ sequestration by mineral carbonation, considering both natural minerals (O'Connor and Dahlin, [1], Haywood et al., [2]) and alkali wastes (Teir et al., [3], Huijgen et al., [4], Anthony et al., [5], Kuusik et al., [6]) as $\mathrm{CO}_{2}$ sorbents.

The other part of the problem is related to the stabilization and safe landfilling of alkaline wastes. Carbonization has been recognized to be an important weathering process affecting alkaline waste materials such as ashes from power plants (Soong et al., [7]; Back et al., [8]; Reddy et al., [9]), and MSWI bottom ash (Meima et al., [10], Ecke, [11]).

The above-mentioned problems concern also the Republic of Estonia, whose energy sector is predominantly (up to 67\%) based on local low-grade fossil fuel - Estonian oil shale. Compared with other fossil fuels, oil shale contains more mineral $\mathrm{CO}_{2}$ in the form of limestone and dolomite. During combustion of oil shale, high temperatures drive off $\mathrm{CO}_{2}$ from carbonate minerals and forming ash contains considerable amounts of $\mathrm{Ca}$ and $\mathrm{Mg}$ oxides (15-30\%), which in certain conditions can be the binders of $\mathrm{CO}_{2}$. Since 1959 the main combustion technology of oil shale has been pulverized firing (PF); in 2004 a more suitable combustion method for low calorific fuel - the circulating fluidized bed combustion (CFBC) was also implemented. The differences between the temperature levels (higher in PF boilers and lower in CFBC boilers) for the new and old boilers influence the phase and chemical composition, as well as the surface characteristics and reactivity of ashes. The objective of this paper is to elaborate the mechanisms of processes deceleration and changes in leaching of some of the $\mathrm{Ca}$ compounds during wet carbonization of ashes at ambient conditions.

\section{Materials and methods}

Initial samples of ash were collected from different points of the ash-separation systems of CFBC and PF boilers at the Estonian Thermal Power Plant. The $\mathrm{CFBC}$ ash samples used for the research were named and marked as follows: intrex ash (CFBC/INT), economizer ash (CFBC/ECO), electrostatic precipitator ash - 1st field (CFBC/ESPA1). The PF ashes used were bottom ash (PF/BA), cyclone ash (PF/CA) and electrostatic precipitator ash - 1st field (PF/ESPA1).

All ash samples were analyzed using chemical, grain-size and quantitative XRD methods, as well as SEM and BET methods (ash properties are discussed in more detail in Kuusik et al., [12]). XRD data was collected in powdered unoriented preparations with a Dron-3M diffractometer using Ni-filtered $\mathrm{Cu}-\mathrm{K} \alpha$ radiation. Digitally registered diffractograms were measured within the range of $2-50^{\circ} 2 \theta$, with $0.03^{\circ} 2 \theta$ step size and 3 s counting time. The diffractograms were analyzed with the code Siroquant using full-profile Rietveld analysis. A scanning 
electron microscope Jeol JSM-8404 was used for surface observations and specific surface area (SSA) was determined with a BET-method at Sorptometer KELVIN 1042 (Costech Microanalytical SC). Porosity measurements were carried out with the high pressure $\mathrm{Hg}$ intrusion method with a porosimeter Quantachrome AutoScan-33 (pressure range 0.1-227 $\mathrm{MPa}$, pore diameter range 6.5-1500 nm).

The carbonization of aqueous ash suspensions with model gas, whose composition $\left(10 \% \mathrm{CO}_{2}\right.$ and $90 \%$ air) simulated $\mathrm{CO}_{2}$ content in flue gases formed at oil shale combustion, was carried out in an absorber (diameter $55 \mathrm{~mm}$, water column height $60 \mathrm{~mm}$ ) equipped with a magnetic stirrer for achieving a better interfacial contact and a sintered glass gas distributor (pore diameter $100 \mu \mathrm{m}$ ). Distilled water or ash transportation water (TDS $=7.79 \mathrm{~g} / 1, \mathrm{Ca}^{2+}$-ions previously precipitated) were used for preparing the suspensions. The solid/liquid ratio was $1 / 10$. Experiments were carried out at room temperature under atmospheric pressure until the suspension reached a definite value of $\mathrm{pH}(10 ; 9 ; 8.5)$. After carbonization, the suspension was filtered and solid residue dehumidified at $105{ }^{\circ} \mathrm{C}$; in the solid residue free $\mathrm{CaO}$ content and $\mathrm{CO}_{2}$ were determined. SSA and pore distribution measurements were performed for investigation of the deceleration mechanism.

In order to elaborate leaching characteristics, ash $\left(\mathrm{CFBC}\right.$ ash, $\mathrm{CaO}_{\text {free }}=8.0 \%$ and $\left.\mathrm{CaSO}_{4}=12.75 \%\right)$ or model mixtures $\left(\mathrm{CaO}\right.$ and $\mathrm{CaSO}_{4}$ of analytical grade) were mixed with water. The solid/liquid ratio was $1 / 10$ in the case of ash. For the model system the amounts of $\mathrm{CaO}$ and $\mathrm{CaSO}_{4}$ were calculated based on the actual contents in ash. Contents of $\mathrm{Ca}^{2+}, \mathrm{Mg}^{2+}, \mathrm{SO}_{4}{ }^{2-}$ (Spectrophotometer Spectrodirect, Lovibond Water Testing) and alkalinity were determined in the liquid phase to study leaching.

\section{Results and discussion}

\subsection{Characterization of oil shale ashes formed at industrial scale boilers}

Reactivity of waste ashes towards $\mathrm{CO}_{2}$ was estimated by their chemical and phase composition (Tables 1,2 ) as well as by physical structure of ash particles (Kuusik et al., [12]). XRD analysis indicated that, as compared to PF ashes, the CFBC ashes contain more calcite (4.0-14.6 and 2.0-5.7\%, respectively) and less free lime (10.8-19.9 and 26.5-29.3\%, respectively). Mg was found in both cases mainly as periclase $(\mathrm{MgO})$. In $\mathrm{CFBC}$ ashes, silica compounds are mainly presented by quartz (up to $17.1 \%$ ) and orthoclase-type K-feldspar (up to $12.5 \%$ ), while PF ashes contain noticeably more secondary silicate - belite (up to $15.9 \%$ ) and merwinite (up to $13.2 \%$ ). Relatively higher content of secondary silicates can be explained by significantly higher temperatures $\left(1250-1400^{\circ} \mathrm{C}\right)$ used in $\mathrm{PF}$ boilers, which leads to the formation of melted phase initiating the reactions between free $\mathrm{CaO}$ and clinker minerals.

Comparison of SEM photos of ash samples shows that particles of CFBC ashes formed at moderate temperatures $\left(750-800^{\circ} \mathrm{C}\right)$ are characterized by an irregular shape as well as by a porous and uneven surface (Fig. 1a). The glassy 
Table 1: Chemical composition and physical properties of CFBC and PF ashes.

\begin{tabular}{|l|l|l|l|l|l|l|}
\hline & $\begin{array}{l}\text { CFBC/ } \\
\text { INT }\end{array}$ & $\begin{array}{l}\mathrm{CFBC} / \\
\text { ECO }\end{array}$ & $\begin{array}{l}\text { CFBC/ } \\
\text { ESPA1 }\end{array}$ & PF/BA & PF/CA & $\begin{array}{l}\text { PF/ } \\
\text { ESPA1 }\end{array}$ \\
\hline $\mathrm{CaO}_{\text {total }} \%$ & 47.59 & 32.84 & 29.52 & 50.75 & 49.39 & 36.08 \\
\hline $\mathrm{MgO}_{\text {total }} \%$ & 13.65 & 9.50 & 8.33 & 15.19 & 14.19 & 11.26 \\
\hline $\mathrm{CaO}_{\text {free }} \%$ & 18.87 & 10.40 & 8.45 & 24.84 & 22.52 & 13.56 \\
\hline $\mathrm{CO}_{2}, \%$ & 1.23 & 5.48 & 4.60 & 2.75 & 0.70 & 1.16 \\
\hline $\mathrm{SSA}, \mathrm{m}^{2} / \mathrm{g}$ & 2.61 & 6.89 & 8.00 & 1.75 & 0.36 & 0.61 \\
\hline $\begin{array}{l}\text { Total intruded } \\
\text { volume, } \mathrm{cm}^{3} / \mathrm{g}\end{array}$ & 0.32 & 0.39 & 0.62 & 0.23 & 0.13 & 0.34 \\
\hline $\mathrm{d}_{\text {mean }}, \mu \mathrm{m}$ & 95 & 27 & 25 & 115 & 48 & 24 \\
\hline
\end{tabular}

Table 2: $\quad$ Mineral composition of CFBC and PF ashes, \%.

\begin{tabular}{|c|c|c|c|c|c|c|}
\hline Minerals & $\begin{array}{l}\text { CFBC/ } \\
\text { INT }\end{array}$ & $\begin{array}{l}\mathrm{CFBC/} \\
\mathrm{ECO}\end{array}$ & $\begin{array}{l}\text { CFBC/ } \\
\text { ESPA1 }\end{array}$ & $\mathrm{PF} / \mathrm{BA}$ & $\mathrm{PF} / \mathrm{CA}$ & $\begin{array}{l}\mathrm{PF} / \\
\text { ESPA1 }\end{array}$ \\
\hline Quartz $\mathrm{SiO}_{2}$ & 5.6 & 17.1 & 16.8 & 3.1 & 3.3 & 12.0 \\
\hline OrthoclaseKAlSi ${ }_{3} \mathrm{O}_{8}$ & 2.7 & 9.4 & 12.5 & 6.6 & 1.7 & 3.8 \\
\hline Albite $\mathrm{NaAlSi}_{3} \mathrm{O}_{8}$ & 2.7 & & & & & \\
\hline $\begin{array}{l}\text { Illite+Illite-Smectite } \\
\mathrm{Na}, \mathrm{K}_{x}(\mathrm{Al}, \mathrm{Mg}) 2 \mathrm{Si}_{4} \mathrm{O}_{10}(\mathrm{OH})_{2} \cdot \mathrm{H}_{2} \mathrm{O}\end{array}$ & 3.1 & 11.2 & 13.8 & & 6.1 & \\
\hline Belite $\mathrm{Ca}_{2} \mathrm{SiO}_{4}$ & 7.3 & 5.8 & 5.3 & 13.5 & 15.9 & 12.3 \\
\hline Merwinite $\mathrm{Ca}_{3} \mathrm{Mg}\left(\mathrm{SiO}_{4}\right)_{2}$ & 5.2 & 3.0 & 3.7 & 9.4 & 13.2 & 6.5 \\
\hline Tricalcium aluminate $3 \mathrm{CaO} \cdot \mathrm{Al}_{2} \mathrm{O}_{3}$ & 1.4 & 2.0 & 2.3 & 2.3 & 2.2 & 2.8 \\
\hline Periclase $\mathrm{MgO}$ & 7.0 & 3.8 & 2.7 & 7.9 & 8.7 & 8.5 \\
\hline Melilite $(\mathrm{Ca}, \mathrm{Na})_{2}(\mathrm{Mg}, \mathrm{Al})(\mathrm{Si}, \mathrm{Al})_{3} \mathrm{O}_{7}$ & 3.6 & 1.6 & 1.2 & 17.8 & 5.8 & 3.3 \\
\hline Anhydrite $\mathrm{CaSO}_{4}$ & 29.9 & 11.1 & 9.5 & 5.4 & 5.4 & 16.8 \\
\hline Gypsum $\mathrm{CaSO}_{4} \cdot 2 \mathrm{H}_{2} \mathrm{O}$ & 0.8 & 0.5 & & & & \\
\hline Lime $\mathrm{CaO}$ & 19.9 & 13.3 & 10.8 & 26.5 & 29.3 & 28.1 \\
\hline Calcite $\mathrm{CaCO}_{3}$ & 4.0 & 14.6 & 13.5 & 5.7 & 2.5 & 2.0 \\
\hline Aragonite $\mathrm{CaCO}_{3}$ & & 0.8 & & & & \\
\hline Portlandite $\mathrm{Ca}(\mathrm{OH})_{2}$ & 2.1 & 0.7 & & & 3.1 & 1.0 \\
\hline Hematite $\mathrm{Fe}_{2} \mathrm{O}_{3}$ & 2.1 & 3.6 & 4.3 & 0.9 & 1.1 & 1.6 \\
\hline Pseudowollastonite $\mathrm{CaSiO}_{3}$ & 1.8 & 1.9 & 3.6 & 0.9 & 1.6 & 0.8 \\
\hline
\end{tabular}

a)

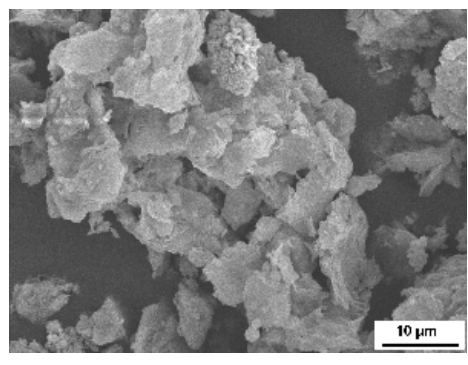

b)

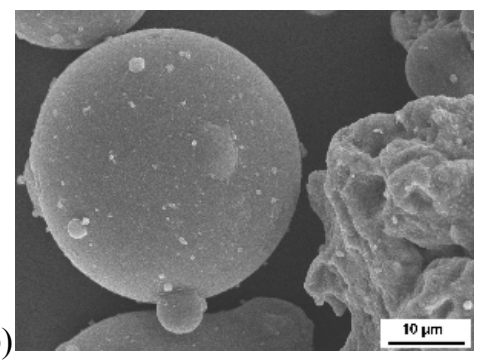

Figure 1: $\quad$ SEM pictures of CFBC (a-CFBC/ESPA1) and PF ashes (b-PF/CA), magnification $2000 \times$. 
phase is not formed. In the case of PF ashes, melting significantly affects the particle shape and surface properties: the particles are characterized by a regular spherical shape with a smooth surface (Fig. 1b).

BET measurements (Table 1) showed significant differences in the physical structure of CFBC and PF ashes - depending on ash type, the differences in SSA were up to a factor of ten. While SSA of CFBC ashes can reach $8.00 \mathrm{~m}^{2} / \mathrm{g}$, the SSA of PF ashes is within $0.36-1.75 \mathrm{~m}^{2} / \mathrm{g}$, which is caused by more intensive sintering of $\mathrm{PF}$ ashes at high boiler temperatures.

\subsection{Transformations in the heterogeneous system $\mathrm{CO}_{2}$ - ash - water: changes in the structure of ash particles}

Laboratory batch tests (Table 3) showed that as compared to PF ashes, CFBC ash can be carbonized more deeply with lowering the content of free lime below $1 \%$. In the case of PF ashes as less-porous materials, some of the free $\mathrm{CaO}$ present is not accessible, especially with $\mathrm{PF} / \mathrm{CA}$, which has the lowest porosity. Electrostatic precipitator ashes are most easily carbonized due to their finer fractional composition (Table 1). Ash transportation water characterized by a high concentration of dissolved salts also inhibits wet carbonization of ash. If ash transportation water was used for preparing the ash suspensions, the carbonization process stopped even earlier and most of the free $\mathrm{CaO}(8.3 \% \mathrm{Abs}$.) remained unreacted.

Pore distribution analysis of initial ashes showed that most of the pore volume of CFBC ashes (CFBC/ESPA1) is contributed by pores in the size range of 0.03 $0.007 \mu \mathrm{m}$ and $0.3-0.1 \mu \mathrm{m}$ (Fig. 3a) as for PF ashes (PF/CA) the dominating pore diameter is considerably smaller - below $0.01 \mu \mathrm{m}$. Thereby, the PF ashes are expected to be more extensively influenced by the formation of reaction products on the surface of particles and pore plugging, which could lower mass transfer rates.

The changes in porosity and pore distribution of ashes at different stages of processing were analyzed to elaborate the deceleration mechanism taking place during the carbonization process. During treatment, while ash containing free $\mathrm{CaO}$ went through hydration, leaching and carbonization processes, both the specific surface area and total intruded volume (TIV) of ash increased (Table 3, Fig. 2) as a contribution from reaction products. The deepness of carbonization did not influence noticeably the value of TIV $\left(0.92-0.98 \mathrm{~cm}^{3} / \mathrm{g}\right.$ in the case of CFBC/ESPA1) ashes. The pore distribution analysis showed that the average pore diameter of hydrated and leached ashes was in the range of 0.007-0.04 $\mu \mathrm{m}$ (Fig. 3). Carbonized ashes had average pore diameter in the ranges of 0.007-0.03 $\mu \mathrm{m}$ and $0.08-0.3 \mu \mathrm{m}$. At deeper carbonization $(\mathrm{pH}=8.5)$ in the case of PF ashes $(\mathrm{PF} / \mathrm{CA})$ the amount of bigger pores (pore diameter in the range of $0.08-0.3 \mu \mathrm{m}$ ) and the value of TIV started to decline.

However, there were no remarkable differences in pore size distribution of ashes carbonized up to definite $\mathrm{pH}$ level (Figure 3c). It seems that in the case of $\mathrm{PF}$ ashes as almost nonporous materials, the reaction products formed hinder 
Table 3: $\quad$ Characterization of initial and carbonized ashes.

\begin{tabular}{|l|l|c|c|c|c|}
\hline Ash & & $\mathrm{CaO}_{\text {free }} \%$ & $\mathrm{CO}_{2}, \%$ & $\mathrm{SSA}, \mathrm{m}^{2} / \mathrm{g}$ & $\mathrm{TIV}, \mathrm{cm}^{3} / \mathrm{g}$ \\
\hline $\mathrm{CFBC} /$ & $\mathrm{Initial}$ & 18.87 & 1.23 & 2.61 & 0.32 \\
$\mathrm{INT}$ & $\mathrm{pH}=10$ & 1.48 & 13.08 & 16.54 & 0.73 \\
& $\mathrm{pH}=9$ & 1.13 & 13.5 & 13.05 & 0.63 \\
& $\mathrm{pH}=8.5$ & 0.94 & 15.14 & 20.56 & 0.72 \\
\hline $\mathrm{CFBC} /$ & $\mathrm{Initial}$ & 10.4 & 5.48 & 6.89 & 0.39 \\
$\mathrm{ECO}$ & $\mathrm{pH}=10$ & 1.03 & 11.84 & 15.35 & 0.64 \\
& $\mathrm{pH}=9$ & 0.5 & 13.1 & 14.76 & 0.63 \\
& $\mathrm{pH}=8.5$ & 0.42 & 13.2 & 15.02 & 0.57 \\
\hline CFBC/ & $\mathrm{Initial}$ & 8.45 & 4.60 & 8.00 & 0.62 \\
ESPA1 & $\mathrm{pH}=10$ & 0.84 & 10.75 & 17.16 & 0.98 \\
& $\mathrm{pH}=9$ & 0.33 & 11.72 & 15.00 & 0.92 \\
& $\mathrm{pH}=8.5$ & 0.38 & 12.88 & 15.88 & 0.94 \\
\hline PF/BA & $\mathrm{Initial}$ & 24.84 & 2.75 & 1.75 & 0.23 \\
& $\mathrm{pH}=10$ & 2.07 & 13.00 & 9.58 & 0.45 \\
& $\mathrm{pH}=9$ & 2.14 & 15.93 & 10.27 & 0.56 \\
& $\mathrm{pH}=8.5$ & 1.57 & 17.12 & 13.18 & 0.51 \\
\hline PF/CA & $\mathrm{Initial}$ & 22.52 & 0.7 & 0.36 & 0.13 \\
& $\mathrm{pH}=10$ & 4.25 & 10.88 & 6.26 & 0.32 \\
& $\mathrm{pH}=9$ & 3.20 & 13.89 & 11.27 & 0.63 \\
& $\mathrm{pH}=8.5$ & 3.24 & 13.16 & 7.20 & 0.32 \\
& $* \mathrm{pH}=10$ & 8.27 & 10.24 & 6.16 & 0.22 \\
& $* \mathrm{pH}=8.5$ & 8.13 & 10.13 & 5.01 & 0.22 \\
\hline PF/ & $\mathrm{Initial}$ & 13.56 & 1.16 & 0.61 & 0.34 \\
ESPA1 & $\mathrm{pH}=10$ & 1.53 & 9.66 & 10.71 & 0.71 \\
& $\mathrm{pH}=9$ & 0.58 & 11.91 & 13.20 & 0.91 \\
& $\mathrm{pH}=8.5$ & 0.40 & 12.15 & 11.45 & 0.87 \\
\hline
\end{tabular}

*Ash transportation water was used for preparing suspension.
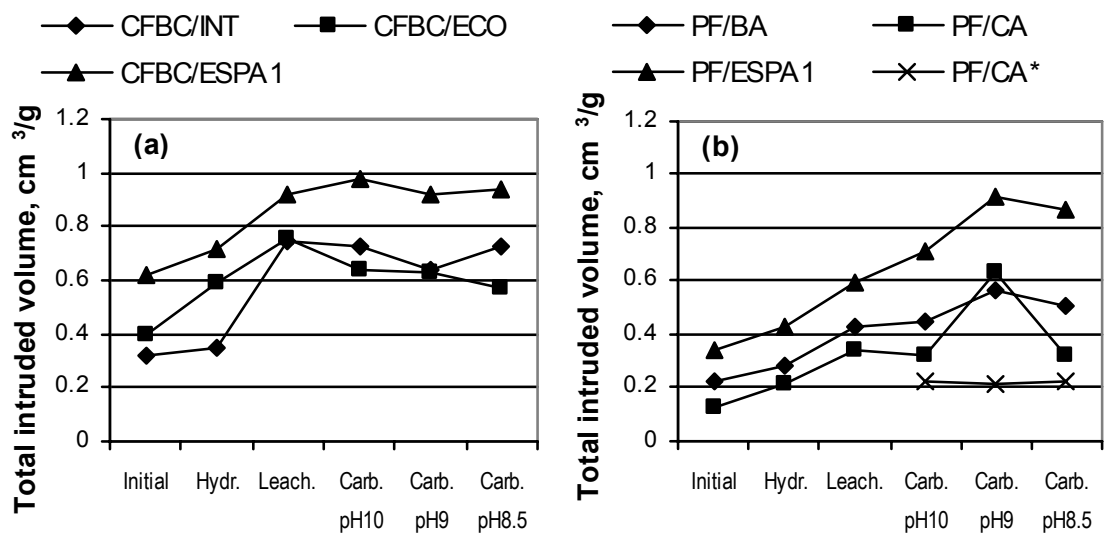

Figure 2: $\quad$ Changes in total porosity of (a) CFBC and (b) PF ashes during different stages of carbonization. 

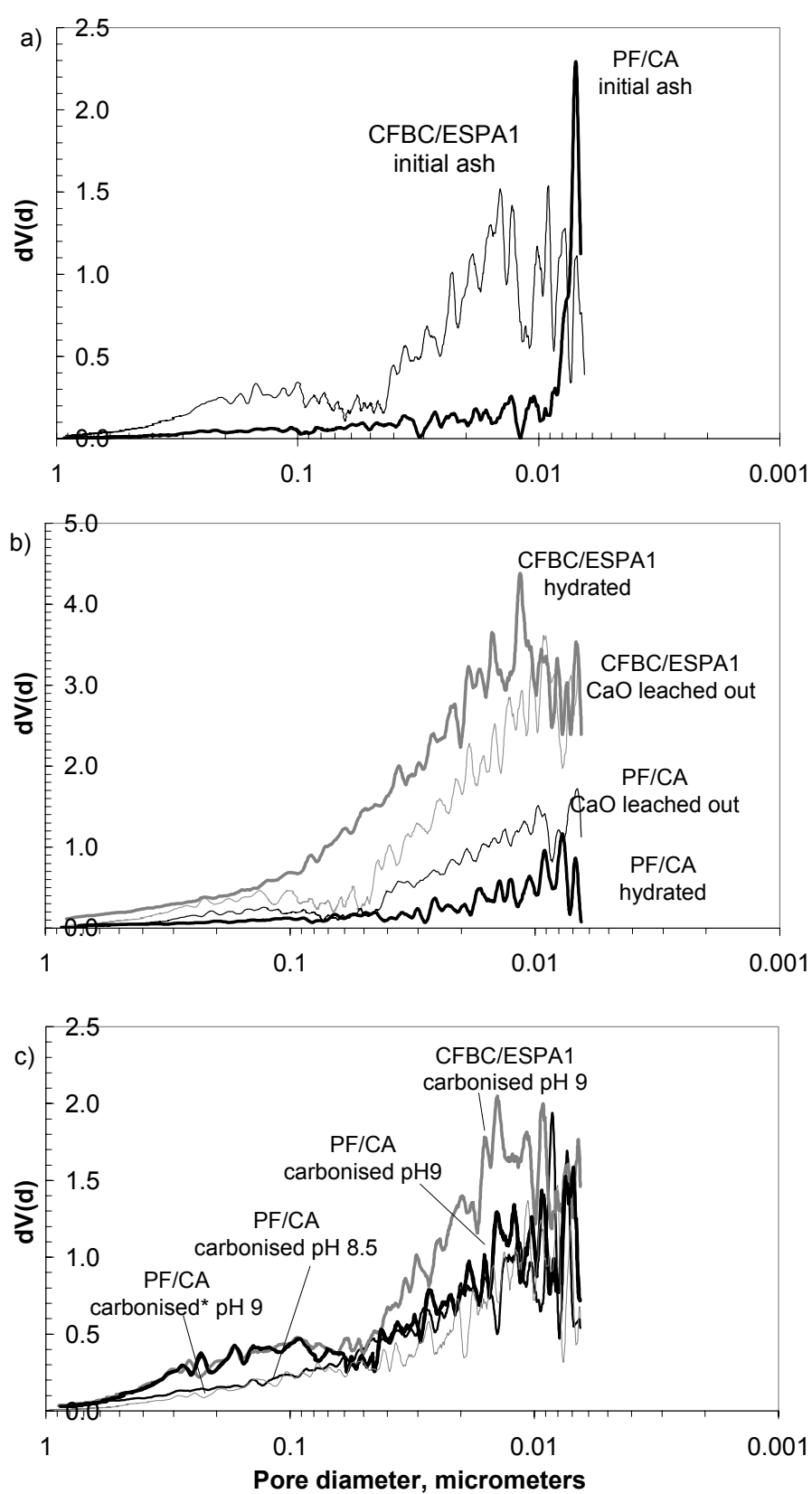

Figure 3: Changes in pore size distribution at hydration, leaching and carbonization of ashes (* - aqueous carbonization process carried out in ash transportation water). 

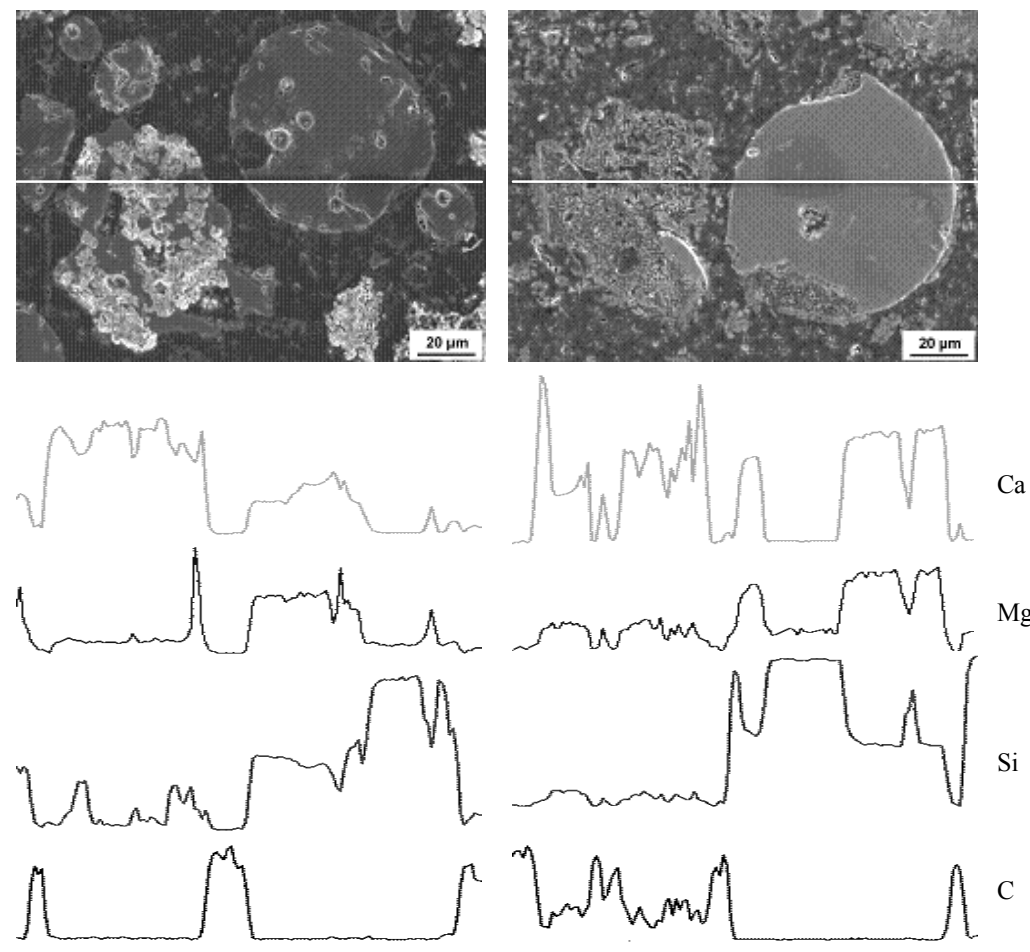

Figure 4: $\quad$ SEM and EDAX analysis of initial ash (PF/CA) and carbonized ash (on left).

reactions with $\mathrm{CaO}$. It was verified also by SEM and EDAX linescan analysis that carbonized particles were covered with a perceptible layer of $\mathrm{CaCO}_{3}$ (Fig. 4). Also, as the initial ash particles contain noticeable amounts of Ca-silicates, which participate at lower $\mathrm{pH}$ in carbonization reactions (Kuusik, et al., [13]), the $\mathrm{SiO}_{2}$ released can block the pores of ash particles.

\subsection{Transformations in the heterogeneous system $\mathrm{CO}_{2}$ - ash - water: leaching of $\mathrm{CaO}$ and $\mathrm{CaSO}_{4}$ at different $\mathrm{pH}$ levels}

Ashes contain considerable amounts of free $\mathrm{CaO}(8-25 \%)$ and $\mathrm{CaSO}_{4}(5-30 \%)$ (Tables 1, 2) which significantly influence the composition of the liquid phase while contacted with water: the liquid phase becomes deeply alkaline $(\mathrm{pH}>12)$ and saturated with $\mathrm{Ca}^{2+}$ and $\mathrm{SO}_{4}{ }^{2-}$ ions. Laboratory experiments showed that the content of $\mathrm{Ca}^{2+}$ decreased significantly during carbonization due to the formation of more stable $\mathrm{CaCO}_{3}$ (Fig. 5). Also, the content of $\mathrm{SO}_{4}{ }^{2-}$ decreased to some extent (1190 and $847 \mathrm{mg} / \mathrm{l}$, respectively) indicating possible co-precipitation of $\mathrm{CaSO}_{4}$. At deeper carbonization to $\mathrm{pH}<8$ the concentrations of $\mathrm{Ca}^{2+}$ and $\mathrm{SO}_{4}{ }^{2-}$ started to rise again (to 480 and $1107 \mathrm{mg} / \mathrm{l}$, respectively). The amount of $\mathrm{Mg}^{2+}$ ions in the solution became evident and bicarbonate ions appeared. Experiments with model systems $\left(\mathrm{CaSO}_{4}-\mathrm{CaO}-\mathrm{H}_{2} \mathrm{O}-\mathrm{CO}_{2}\right)$ confirmed the same tendencies. 


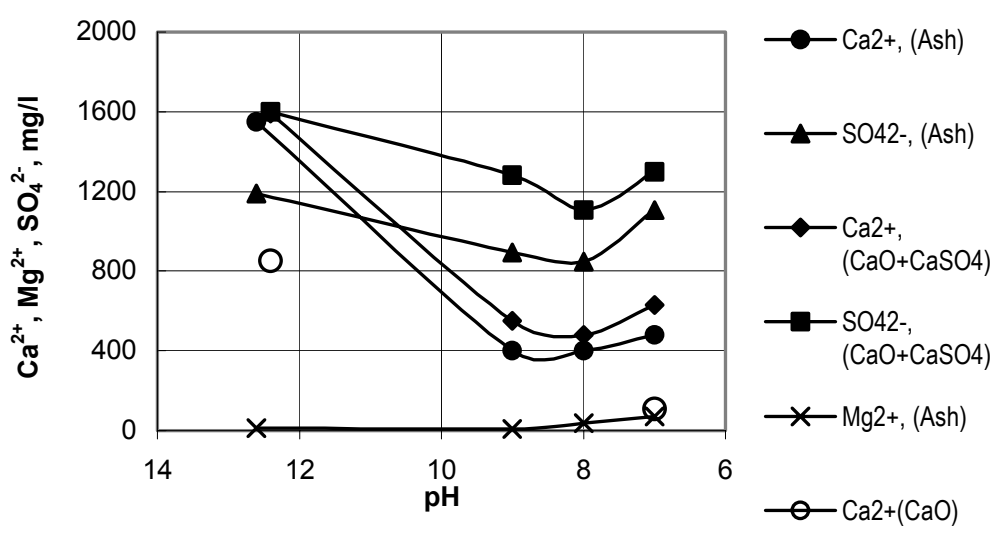

Figure 5: Changes in liquid phase composition during carbonization of aqueous suspensions of ash and model compounds.

Therefore, while using a wet carbonization method for stabilizing the ashes, it is recommended to keep final $\mathrm{pH}$ in the range of $8 . . .9$ - going to lower values would increase the leaching of some ash components.

\section{Conclusions}

The deceleration mechanism of the wet carbonization process of two kinds of oil shale ashes has been elaborated. The CFBC ashes, characterized by a porous and uneven surface as well as higher SSA values and larger pores, can be carbonized more deeply with lowering the content of free $\mathrm{CaO}$ below $1 \%$.

Due to low porosity and small sized pores, the PF ashes are rather extensively influenced by product $\left(\mathrm{CaCO}_{3}\right)$ formation on the surface of particles. Evidently, in this case the formation of reaction products leads to the plugging of pores in extent hindering the leaching of lime and diffusion of $\mathrm{Ca}^{2+}$-ions.

The carbonization process is also controlled by a liquid phase - by the $\mathrm{pH}$ of ash - water suspension. At lower $\mathrm{pH}$ values carbonization process may decelerate due to the increase in solubility of calcium carbonate and sulphate.

\section{Acknowledgements}

Partial funding of this work by ESF (G6195), Nordic Energy Research and SC Narva Elektrijaamad is appreciated. The contribution of Dr Valdek Mikli in the performance of SEM measurements is acknowledged.

\section{References}

[1] O'Connor, W.K., Dahlin, D.C., $\mathrm{CO}_{2}$ storage in solid form: a study of direct mineral carbonation. 5th International Conference on Greenhouse Gas Technologies, Cairns, Australia, 2000. 
[2] Haywood, H.M, Eyre, J.M., Scholes, H., Carbon dioxide sequestration as stabile carbonate minerals - environmental barriers. Environmental Geology, 41, pp. 11-16, 2001.

[3] Teir, S., Eloneva, S., Zevenhoven, R., Co-utilization of $\mathrm{CO}_{2}$ and calcium silicate-rich slags for precipitated calcium carbonate production (part I). Proc. of ECOS 2005, Trondheim, pp.749-756, 2005.

[4] Huijgen, W.J.J., Witkamp, G.J., Comans, R.N.J., Mineral $\mathrm{CO}_{2}$ sequestration by steel slag carbonation. Environmental Science and Technology, 39(24), pp. 9676-9682, 2005.

[5] Anthony, E. A., Jia, L., Woods, J., Roque, W., Burwell, S., Pacification of high calcic residues using carbon dioxide. Waste Management, 20, pp. 113, 1999.

[6] Kuusik, R., Veskimäe, H., Kaljuvee, T., Parts, O., Carbon dioxide binding in the heterogeneous systems formed by combustion of oil shale. 1 . Carbon dioxide binding at oil shale ash deposits. Oil Shale, 18(2), pp.109122, 2001.

[7] Soong, Y., Fauth, D.L, Howard, B.H., Jones, J.R., Harrison, D.K., Goodman, A.L., Gray, M.L., Formell, E.A., $\mathrm{CO}_{2}$ Sequestration with brine solution and fly ashes. Energy Conversion \& Management, 47, pp.16761685,2005

[8] Back, M., Vosbeck, K., Kühn, M., Stanjek, H., Clauser, C., Peiffer, S., Pretreatment of $\mathrm{CO}_{2}$ with fly ashes to generate alkalinity for subsurface sequestration. Proc. of GHGT-8, Trondheim, Norway, 2006.

[9] Reddy, K. J., Drever, J.I., Hasfurther, V.R., Effects of a pressure process on the solubilities of major and trace elements in oil shale solid wastes. Environ. Sci. Technol., 25, pp. 1466-1469, 1991.

[10] Meima J. A., van der Weijden, R.D., Taylor Eighmy, T., Comans, R.N.J., Carbonation process in municipal solid waste incinerator bottom ash and their effect on the leaching of copper and molybdenum. Applied Geochemistry, 17, pp. 1503-1513, 2001

[11] Ecke H. Sequestration of metals in carbonated municipal solid waste incineration (MSWI) fly ash. Waste Management, 23, pp. 631-640, 2003.

[12] Kuusik, R., Uibu, M., Kirsimäe, K., Composition and physico-chemical characterization of oil shale ashes formed at industrial scale boilers with CFBC. Oil Shal,e 22(4S), pp. 407-419, 2005.

[13] Kuusik, R., Türn, L., Trikkel, A., Uibu, M., Carbon dioxide binding in the heterogeneous systems formed at combustion of oil shale. 2. Integrations of system components - thermodynamic analysis. Oil Shale, 19(2), pp.143-160, 2002. 